BIODIK: Jurnal IImiah Pendidikan Biologi
ISSN 2580-0922 (online), ISSN 2460-2612 (print)
Volume 7, Nomor 02, Tahun 2021, Hal. 153-162
Available online at:
hiOttps://online-journal.unja.ac.id/biodik

Research Article

OPEN ACCESS

\title{
Pengembangan Media Pembelajaran Teka-Teki Silang IPA Terpadu Untuk Siswa Kelas VII SMPN 56 Merangin
}

\author{
(Development of Integrated Science Crossword Learning Media for Class VII Students of SMPN \\ 56 Merangin)
}

Eni Yulianti ${ }^{*}$, Andriyanto

Program Studi Pendidikan Biologi, STKIP YPM Bangko

JL. Jenderal Sudirman, Komplek STKIP, Bangko, Kabupaten Merangin, Jambi 37313-Indonesia

*Correponding Author : eni.yulianti1618@gmail.com

\begin{tabular}{|c|c|}
\hline Informasi Artikel & ABSTRACT \\
\hline $\begin{array}{l}\text { Submit: } 10-11-2020 \\
\text { Diterima: } 12-04-2021 \\
\text { Dipublikasikan:09 - } 06-2021\end{array}$ & $\begin{array}{l}\text { Learning media is a teacher's tool in delivering teaching materials. Fun learning } \\
\text { media will make students happy in learning. This will certainly make student } \\
\text { learning outcomes better. The purpose of this research is to produce an } \\
\text { integrated science crossword puzzle learning media product on the material } \\
\text { classification of living things and material classification and changes for class } \\
\text { VIII SMP N } 56 \text { Merangin which is valid, practical and effective. The method } \\
\text { used to produce these products is the Development research method, namely } \\
\text { the four-D development model. The four-D development model consists of four } \\
\text { stages, namely the definition stage, the design stage, the development stage } \\
\text { and the dissemination stage. The results of this product validation are very valid } \\
\text { from the language aspect with a value of } 92.5 \% \text {, material aspects } 85.4 \% \text {, } \\
\text { presentation and graphic aspects } 85 \% \text {. The criteria for the practicality of the } \\
\text { media are very practical and the completeness of learning outcomes using the } \\
\text { Integrated Science TTS media is } 75 \% \text {. }\end{array}$ \\
\hline & Key words: crossword puzzle, valid,practikality \\
\hline Penerbit & ABSTRAK \\
\hline $\begin{array}{l}\text { Program Studi Pendidikan Biologi } \\
\text { FKIP Universitas Jambi, } \\
\text { Jambi- Indonesia }\end{array}$ & $\begin{array}{l}\text { Media belajar adalah alat bantu guru dalam menyampaikan materi ajar. Media } \\
\text { belajar yang menyenangkan akan membuat siswa menjadi senang dalam } \\
\text { belajar. Hal ini tentu akan membuat hasil belajar siswa menjadi baik. Tujuan } \\
\text { dari penelitian ini adalah menghasilkan produk media pembelajaran Teka-Teki } \\
\text { Silang IPA Terpadu pada materi klasifikasi makhuk hidup dan klasifikasi materi } \\
\text { dan perubahannya untuk kelasVII SMP N } 56 \text { Merangin yang valid, praktis dan } \\
\text { efektif. Metode yang digunakan untuk menghasilkan produk tersebut adalah } \\
\text { metode penelitian Pengembangan yaitu model pengembangan four-D. Model } \\
\text { pengembangan four - } D \text { terdiri dari empat tahap yaitu tahap pendefinisian } \\
\text { (define), tahap perancangan (design), tahap pengembangan (develop) dan } \\
\text { tahap penyebaran (disseminate). Hasil validasi produk ini adalah sangat valid } \\
\text { dari aspek bahasa dengan nilai } 92,5 \% \text {, aspek materi } 85,4 \% \text {, aspek penyajian } \\
\text { dan kegrafikan } 85 \% \text {. Kriteria praktikalitas media sangat praktis dan ketuntasan } \\
\text { hasil belajar menggunakan media TTS IPA Terpadu } 75 \% \text {. }\end{array}$ \\
\hline & Kata kunci: Teka-teki silang, valid, praktikalitas \\
\hline
\end{tabular}




\section{PENDAHULUAN}

Media belajar adalah salah satu alat pelajaran yang sangat menentukan keberhasilan pembelajaran (Sadikin et al., 2020). Salah satu bentuk inovasi dalam pendikan yang dapat dilakukan adalah inovasi dan pengembangan media belajar. Menurut Media belajar adalah semua komponen sumber belajar atau wahana fisik yang mengandung materi intruksional di lingkungan siswa yang dapat merangsang siswa untuk belajar (Slameto, 2016). Pengembangan media belajar dapat dilakukan disemua jenjang pendidikan dan semua mata pelajaran termasuk mata pelajaran IPA Terpadu. Akan tetapi, berdasarkan hasil pengamatan dan wawancara penulis dengan guru mata pelajaran IPA Terpadu di SMP 56, belum ada pengembangan media pembelajaran IPA Terpadu. Sementara itu, pelajaran IPA Terpadu adalah salah satu pelajaran yang dirasa sulit bagi siswa. Pengembangan media belajar sangat penting dilakukan karena media belajar dapat meningkatkan kesukaan siswa terhadap pelajaran. Jika siswa semakin suka terhadap proses pembelajaran, maka siswa akan terus menerus belajar, sehingga pemahaman siswa dalam belajar akan semakin baik. Oleh sebab itu, pengembangan media pembelajaran terus dilakukan. Salah satu media pembelajaran yang dikembangkan adalah media Teka-Teki silang (TTS). Teka-Teki Silang (TTS) adalah media pembelajaran yang memiliki unsur permainan, sehingga dapat membuat siswa mengalami suasana belajar yang menyenangkan. Menurut (Maryanti \& Kurniawan, 2017) Penggunaan media TTS menjadikan peserta didik termotivasi dan bergairah mempelajari kosakata yang dapat merangsang daya nalarnya untuk memahami materi, sehingga dapat mudah diingat dan menjadi pengetahuan yang sangat berkesan dan tidak mudah dilupakan sebagai sebuah pengalaman belajar. Oleh karena manfaat media pembelajaran Teka-Teki Silang (TTS) sangat bagus dan di SMPN 56 Merangin belum pernah dikembangkan media pembelajaran Teka-Teki Silang (TTS) maka peneliti melakukan pengembangan media pembelajaran Teka-Teki Silang (TTS) IPA Terpadu. Agar pengembangan yang dilakukan lebih fokus maka pengembangan dilakukan pada materi klasifikasi makhluk hidup dan klasifikasi materi dan perubahannya di kelas VII.

Penelitian pengembangan media pembelajaran Teka-Teki Silang (TTS) sudah pernah dilakukan oleh beberapa peneliti sebelumnya. Penelitian pertama oleh (Nazeer et al., 2018) berjudul "Crossword Puzzles as an Active Learning Mode for Student Directed Learning in Anatomy Teaching: Medical Undergraduate Perceptions" menjelaskan bagaimana persepsi mahasiswa terhadap penggunaan media teka-teki silang dalam pembelajaran. Hal ini didasarkan pada permasalahan pembelajaran di perguruan tinggi di India yang pada umumnya belum berpusat pada mahasiswa sehingga mahasiswa kurang aktif dalam pembelajaran. Oleh karena itu, penelitian ini mengembangkan media pembelajaran berupa teka-teki silang menggunakan software eclipscrssword. Konten dan format latihan dari teka-teki silang yang dikembangkan di validasi oleh ahli dari jurusan anatomi. Teka-teki silang yang dikembangkan kemudian di sebarkan kepada subjek penelitian untuk mendapatkan data persepsi mahasiswa. Hasil dari penelitian ini adalah $80 \%$ siswa sangat setuju bahwa memecahkan teka-teki silang adalah pengalaman yang menyenangkan, 79\% siswa menikmati proses belajar, $73 \%$ siswa merasakan pemahaman mereka tentang topik membaik sebagai hasil dari aktivitas teka-teki silang, 60\% siswa merasa bahwa aktivitas teka-teki silang menantang pemecahan masalah, 65\% siswa sangat merasa bahwa teka-teki silang mempromosikan pembelajaran aktif dan $71 \%$ siswa merasa bahwa Teka-Teki Silang membantu mereka untuk mengingat istilah-istilah penting dari topik, dan $65 \%$ siswa merekomendasikan penggunaan teka-teki silang untuk pembelajaran. Berdasarkan hasil tersebut 
penelitian ini menyimpulkan bahwa media teka-teki silng dapat memperkuat konsep dan pembelajaran aktif.

Berdasarkan (Wasgito, 2014) media pembelajaran teka-teki silang juga dikembangkan untuk siswa SMP. Penelitiannya yag berjudul "Pengembangan Media Permainan Edukatif Teka-Teki Silang (tts) dalam Proses Pembelajaran Siswa Kelas VII SMP Negeri 2 Kalianget" menjelaskan pengembangan media pembelajaran teka-teki silang untuk siswa SMP pada mata pelajaran seni budaya. Hasil penelitian ini menyatakan bahwa hasil validasi pada kualitas aspek kompetensi berkategori "baik" dengan rata $80 \%$. Secara keseluruhan pengamatan aktifitas siswa dalam pembelajaran seni budaya pada materi seni rupa terapan dengan menggunakan media teka- teki silang dikategorikan sangat baik dengan presentasi $86 \% \%$. Hasil belajar menggunakan media teka-teki silang yaitu $87,5 \%$ dinyatakan lulus.

Teka-teki silang adalah sebuah permainan yang dapat digunakan sebagai media pembelajaran. Media ini juga bagus dikembangkan untuk anak usia Sekolah Dasar (SD) (Lestari \& Sb, 2017). Penelitian berjudul 'Development of Crossword Puzzles as Teaching Tools in Explanatory Texts Learning" membahas tentang proses pengembangan media teka-teki silang untuk siswa kelas 5 SD. Pada penelitian tersebut, media Teka-Teki Silang yang dikembangkan di validasi dari segi media dan isi. Efektifitas dilihat dari hasil belajar siswa mengunakan Teka- Teki Silang. Hasil penelitian ini menyatakan bahwa teka-teki silang yang dikembanngkan sangat layak digunakan dengan persentase penilaian $89,58 \%$, penilaian ahli materi $88,63 \%$. Hasil test sebelum menggunakan media adalah 51,02 dan setelah menggunakan media 76,11.

Penelitian tentang penerapan media pembelajaran teka-teki silang dalam pembelajaran juga sudah berhasil dilakukan (Akbar \& Arbi, 2018). Penelitian ini berjudul Application of Crossword Puzzles to Increase Student's Learning Outcome on Motion System Material of Biology. Penelitian ini dilakukan dua kali siklus dengan memberikan test pada setiap akhir siklus. Test dilakukan untuk mengetahui hasil belajar siswa. Hasil penelitian ini menyatakan bahwa hasil belajar siswa meningkat dengan persentase rata-rata 39,90 dengan kategori kurang menjadi 79,70 pada kategori baik. Sehingga kesimpulan dari penelitian ini adalah media pembelajaran teka-teki silang dapat meningkatkan hasil belajar siswa pada mata pelajaran biologi materi sistem gerak.

Penelitian yang berkaitan media pembelajaran Teka-Teki Silang (TTS) menunjukkan bahwa media pembelajaran teka-teki silang sangat baik digunakan dalam pembelajaran. Media pembelajaran dapat menciptakan pembelajaran aktif, menguatkan konsep dan meningkatkan hasil belajar. Selain itu media pembelajaran teka-teki silang sesuai dikembangkan untuk siswa SD hingga perguruan tinggi. Oleh karena sangat banyak manfaat dari media ini maka pengembangan media pembelajaran sangat penting dilakukan.

Pada penelitian ini terdapat perbedaan bila dibandingkan dengan 4 penelitian sebelumnya. Perbedaan dengan penelitian pertama yaitu produk divalidasi oleh ahli materi, bahasa dan kegrafikan, sedangkan pada penelitian sebelumya validasi hanya dilakukan oleh ahli materi. Pada penelitian ini, produk disebarkan kepada guru dan siswa untuk mengetahui tingkat praktikalitas produk. Selain itu, keefektifan produk dilihat dari hasil belajar siswa, sedangkan penelitian sebelumnya produk disebarkan kepada mahasiswa untuk mengetahui persepsi mahasiswa terhadap penggunaan teka-teki silang 
dalam pembelajaran. Pada penelitian ini Teka-teki silang yang dikembangkan untuk siswa SMP, sedangkan pada penelitian sebelumnya untuk mahasiswa jurusan kedokteran. Penelitian ini dilaksanakan sampai tahap penyebaran, sedangkan penelitian sebelumnya tidak. Perbedaan dengan penelitian kedua yaitu mata pelajaran yang digunakan untuk mengembangkan teka-teki silang pada penelitian ini adalah mata pelajaran IPA Terpadu, sedangkan pada penelitian sebelumnya pada mata pelajaran seni budaya. Penelitian ini dilaksanakan hingga tahap penyebaran sedangkan penelitian sebelumnya hanya sampai tahap pengembangan. Perbedaan dengan penelitian ketiga yaitu Subjek penelitian ini adalah siswa SMP kelas VII, sedangkan pada penelitian sebelumnya adalah siswa SD kelas V. Mata pejalaran Teka-Teki Silang pada penelitian ini adalah IPA Terpadu, sedangkan mata pelajaran pada penelitian sebelumnya adalah Bahasa Indonesia. Penelitian ini dilaksanakan sampai tahap penyebaran, sedangkan penelitian sebelumnya hanya pada tahap pengembangan. Perbedaan dengan penelitian keempat yaitu Penelitian ini merupakan penelitian pengembangan, sedangkan penelitian sebelumnya merupaka penelitian tindakan kelas. Pada penelitian ini menghasilkan produk Teka-Teki Silang sedangkan pada penelitian sebelumnya produk telah siap digunakan dan tidak dijelaskan validitas produk. Pada penelitian ini Teka-teki silang untuk SMP, sedangkan pada penelitian sebelumnya untuk siswa SMA.

\section{METODE PENELITIAN}

Penelitian ini dilaksanakan di SMP 56 Merangin yang terletak di kecamatan Pamenang Barat Kabupaten Merangin Provinsi Jambi. Penelitian dilaksanakan pada bulan maret sampai november tahun Pelajaran 2020/2021. Jenis rancangan penelitian ini adalah penelitian dan pengembangan atau Research and Development. Research and Development adalah metode penelitian yang digunakan untuk menghasilkan produk tertentu dan menguji keefektifan produk tersebut (sugiono, 2011). Produk yang dihasikan berupa Media Pembelajaran Teka-Teki Silang (TTS) IPA Terpadu pada materi klasifikasi makhluk hidup dan klasifikasi materi dan perubahannya. Penelitian pengembangan ini menggunakan model pengembangan four-D (Four D Model). Menurut Thiagarajan tahap-tahap model pengembangan four- $D$ terdiri dari empat tahap yaitu tahap pendefinisian (define), perancangan (design), pengembangan (develop) dan penyebaran (disseminate) (sugiono, 2011)

Tahap pertama adalah tahap pendefinisian. Pada tahap pendefinisian dilakukan untuk mendapatkan gambaran tentang kondisi siswa yang berupa karakter siswa dan materi serta konsepkonsep yang diajarkan di sekolah tersebut. Pada tahap pendefinisian penulis melakukan analisis terhadap kurikulum yang digunakan, analisis kebutuhan siswa terhadap media pembelajaran yang akan dibuat serta analisis materi yang diajarkan. Setelah diperoleh hasil dari tahap pendefinisian kemudian dirancanglah sebuah produk media pembelajaran. Produk yang telah dirancang tersebut divalidasi oleh para ahli. Proses validasi meliputi validasi materi kebahasaan, penyajian dan kergafikan. Produk yang sudah dinyatakan valid oel pada ahlli kemudian diujicobakan kepada siswa kelas VII SMPN 56 Merangin. Uji coba produk dilakukan untuk memperoleh data praktilas dan efektifitas produk. Produk yang teah praktis dan efektif kemudian disebarkan di SMPN 56 Merangin dan SMPN 6 Merangin.

Teknik pengumpulan data dilakukan dengan cara observasi, wawancara, angket dan dokumentasi. Observasi dilakukan dengan mengamati karakter siswa SMPN 56 merangin. Wawancara dilakukan kepada guru bidang studi untuk memperoleh infomasi tentang karakter siswa dalam proses pembelajaran,kurikulum yang digunakan kedalaman materi yang diajarkan, media yang digunakan 
serta pengembangan media pembelajaran yang pernah dilakukan. Data peneilitian juga diperoleh dari hasil angket validasi dan angket praktikalitas. Angket validasi disebarkan kepada ahli (validator) dibidangnya masing-maasing. Hal ini dilakukan untuk memperoleh data validitas media pembelajaran Teka-Teki Silang (TTS) IPA Terpadu. Angket praktikalitas kepada siswa untuk memperoleh data praktikalitas. Selanjutnya, data efektifitas diperoleh dengan memberikan soal test kepada siswa.

Data praktikalitas didapat dari angket respon siswa berkaitan dengan penggunaan media pembelajaran yang telah dibuat. Analisis praktikalitas dilakukan dengan menggunakan skala likert (1-4). Perhitungan nilai akhir hasil praktikalitas dinyatakan dalam skala (0-100), dilakukan dengan menggunakan persamaan 2 (Riduwan, 2006). Efektivitas media pembelajaran dalam penelitian ini dilakukan menggunakan hasil belajar peserta didik dari aspek Pengetahuan. Pada kompetensi pengetahuan dan keterampilan peserta didik dikategorikan tuntas apabila telah mencapai KKM. KKM yang ditetapkan di SMPN 56 Merangin berdasarkan kurikulum 2013 untuk kompetensi pengetahuan adalah 75 dan KKM secara klasikal sebesar $75 \%$.

\section{HASIL PENELITIAN DAN PEMBAHASAN}

Hasil dari penelitian ini adalah produk media pembelajaran Teka-Teki Silang (TTS) IPA Terpadu yang valid, praktis dan efektif. Tahap pendefinisian dilakukan dengan melakukan analisis kurikulum, materi dan siswa. Hasil dari tahap pendefinisian adalah kurikulum yang digunakan di SMP N 56 Merangin adalah kurikulum 2013. Oleh karena itu isi media TTS IPA Terpadu yang dirancang mengacu pada kurikulum 2013. Isi tersebut meliputi tujuan dan indikator pembelajaran, materi, dan pertanyaan di dalam media TTS IPA Terpadu. Hasil analisis terhadap siswa adalah karakter siswa SMP N 56 yang cenderung senang bermain dan menyukai hal baru. Selain itu, penulis melakukan analisis kebutuhan terhadap media pembelajaran TTS IPA Terpadu untuk mendapatkan informaasi tentang kebutuhan penyajian. Jika dibandingkan dengan penelitian sebeumnya, penelitian ini sejalan dengan penelitian Andi wasgito....yang melakukan analisis kebutuhan sebelum merancang produk. Analisis kebutuhan ini dapat membantu mengarahkan penulis dalam merancang produk agar sesuai dengan minat siswa. Berdasarkan hasil analisis kebutuhan teersebut diperoleh informasi bahwa siswa sangat setuju dengan pengembangan media pembelajaran yang akan dilaksanakan di sekolahnya. Tahap ini juga memberkan informasi tentang rancangan penyajian media TTS IPA Terpadu yang meliputi huruf yang digunakan adalah huruf comic son, warna yang disukai siswa adalah dominan warna biru dan merah, serta siswa menyukai gambar animasi yang lucu. Setelah tahap pendefinisian dirasa cukup maka dilanjutkan ke tahap perancangan yang disesuaikan dengan hasil dari tahap pendefinisian.

Tahap perancangan meliputi perancangan cover, kata pengantar, daftar isi, kompetensi inti dan kompetesi dasar, tujuan dan indikator, ringkasan materi, pertanyaan TTS dan design kotak TTS, gambar animasi dan daftar pustaka. Sebelum memproduksi media pembelajara TTS IPA Terpadu penulis terlebih dahulu mengumpulkan literatur untuk menyusun materi dan pertanyaan yang sesuai dengan tujuan pembelajaran pada kurikuum 2013. Penulis juga menngumpulkan gambar animasi yang menarik untuk disajikan dalam media pembelajaran TTS IPA Terpadu. TTS dirancang dengan ukuran A5 agar mudah dibawa oleh siswa. Warna media TTS IPA Terpadu yang dirancang adalah dominan biru dan dipadukan dengan warna merah. Bagian cover diberi identitas materi yang termuat dalam 
media. Selain itu diberi gambar yang disesuaikan dengan materi yang ada dalam media TTS IPA Terpadu. Gambar 1 adalah design media pembelajaran TTS IPA Terpadu.

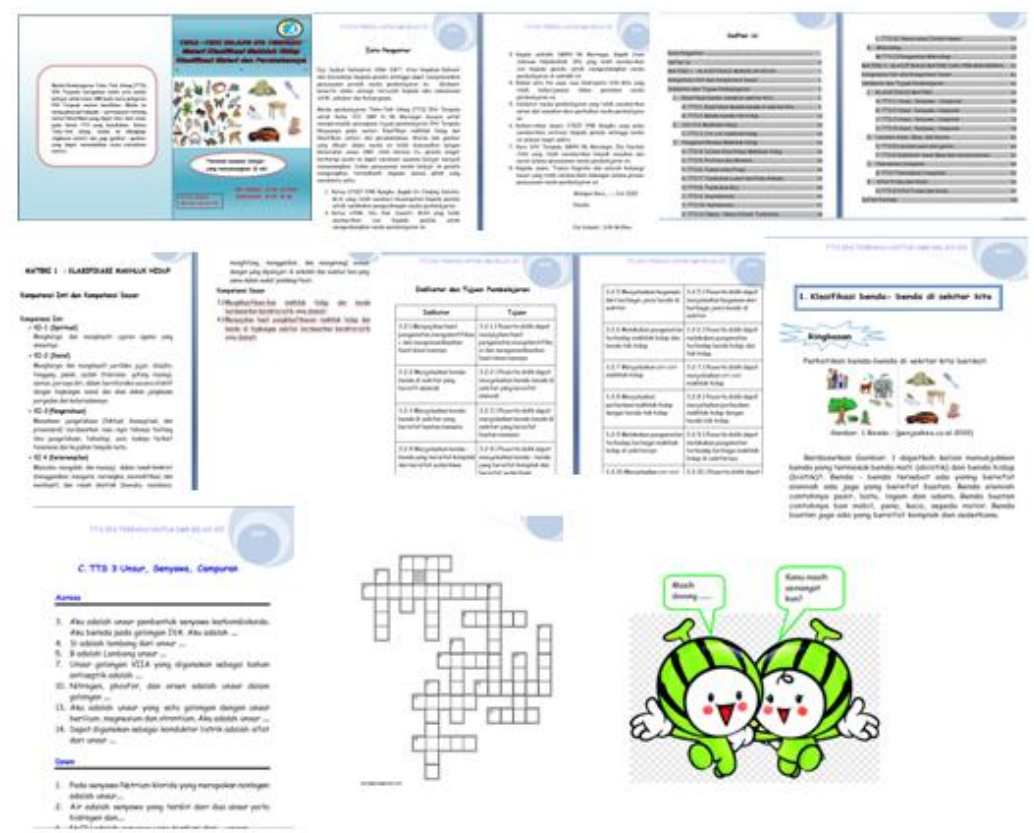

Gambar 1. Rancangan media pembelajara Teka-Teki Silang (TTS) IPA Terpadu

Media pembelajaran TTS IPA Terpadu di design se menarik mungkin agar siswa merasa suka belajar menggunakan media TTS. Bentuk kotak-kotak TTS juga di buat bervariasi agar siswa tidak bosan. Gambar animasi juga bervariasi dan lucu. Setelah tahap perancangan selesai, selanjutnya produk dicetak. Media TTS IPA Terpadu ini dicetak secara bolak-balik menggunakan kertas A4. Gambar 2. Adalah contoh media pembelajaran yang sudah jadi.
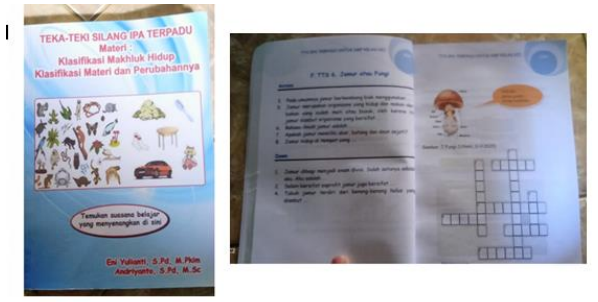

\section{Gambar 2. Hasil jadi media pembelajara Teka-Teki Silang (TTS) IPA Terpadu}

Setelah media pembelajaran TTS IPA Terpadu dicetak, selanjutnya dilakukan validasi. Validasi adalah proses pengujian kebenaran. Tahap validasi ini sedikit berbeda dengan penelitian yang dilakukan oleh (Nazeer et al., 2018) dengan judul "Crossword Puzzles as an Active Learning Mode for Student Directed Learning in Anatomy Teaching: Medical Undergraduate Perceptions". Pada penelitian tersebut peneliti hanya melakukan validasi kepada ahli materi sementara itu pada penelitian ini dilakukan empat jenis validasi. Validasi tersebut adalah validasi materi, kebahasaan penyajian dan kegrafikan. Dengan demikian diharapkan keunggulan dari media pembelajaran TTS IPA Terpadu ini adalah teruji kebenarannya dari segi materi, bahasa, penyajian dan kegrafikan. Hasil validasi dapat dilihat dari tabel 1. 
Tabel 1. Hasil Valildasi Media Pembelajaran IPA Terpadu

\begin{tabular}{|c|c|c|c|c|c|c|c|c|}
\hline No & Aspek & \multirow{2}{*}{$\begin{array}{l}\text { No } \\
\text { Item }\end{array}$} & \multicolumn{2}{|c|}{ Penilaian Validator } & \multirow{2}{*}{$\begin{array}{c}\text { Jumah skor } \\
\text { yang } \\
\text { diperoleh }\end{array}$} & \multirow{2}{*}{$\begin{array}{c}\text { Jumlah skor } \\
\text { seluruhya }\end{array}$} & \multirow{2}{*}{$\begin{array}{c}\text { Nillai } \\
\text { Validasi }\end{array}$} & \multirow[b]{2}{*}{ Kategor } \\
\hline \multirow{7}{*}{$A$} & & & Vaidator 1 & Validator II & & & & \\
\hline & Bahasa & 1 & 3 & 3 & 6 & 8 & \multirow{6}{*}{$92,5 \%$} & \multirow{6}{*}{$\begin{array}{l}\text { Sangat } \\
\text { valid }\end{array}$} \\
\hline & & 2 & 4 & 4 & 8 & 8 & & \\
\hline & & 3 & 4 & 4 & 8 & 8 & & \\
\hline & & 4 & 4 & 4 & 8 & 8 & & \\
\hline & & 5 & 4 & 3 & 7 & 8 & & \\
\hline & Jumlah & & 19 & 18 & 37 & 40 & & \\
\hline \multirow{13}{*}{ B } & & 1 & 4 & 4 & 8 & 8 & \multirow{13}{*}{$85,4 \%$} & \multirow{13}{*}{$\begin{array}{l}\text { Sangat } \\
\text { valid }\end{array}$} \\
\hline & & 2 & 3 & 3 & 6 & 8 & & \\
\hline & & 3 & 4 & 4 & 8 & 8 & & \\
\hline & & 4 & 4 & 4 & 8 & 8 & & \\
\hline & & 5 & 3 & 3 & 6 & 8 & & \\
\hline & Isi & 6 & 3 & 4 & 7 & 8 & & \\
\hline & 101 & 7 & 3 & 3 & 5 & 8 & & \\
\hline & & 8 & 3 & 3 & 3 & 8 & & \\
\hline & & 9 & 3 & 4 & 5 & 8 & & \\
\hline & & 10 & 4 & 4 & 8 & 8 & & \\
\hline & & 11 & 4 & 3 & 7 & 8 & & \\
\hline & & 12 & 3 & 3 & 4 & 8 & & \\
\hline & Jumlah & & 41 & 42 & 83 & 96 & & \\
\hline \multirow{11}{*}{ C } & & 1 & 3 & 4 & 7 & 8 & \multirow{11}{*}{$85 \%$} & \multirow{11}{*}{$\begin{array}{l}\text { Sangat } \\
\text { valid }\end{array}$} \\
\hline & & 2 & 3 & 3 & 5 & 8 & & \\
\hline & & 3 & 3 & 4 & 6 & 8 & & \\
\hline & Penyaijian & 4 & 4 & 4 & 8 & 8 & & \\
\hline & dan & 5 & 4 & 3 & 8 & 8 & & \\
\hline & kegrafikan & 6 & 3 & 3 & 7 & 8 & & \\
\hline & keyrallkall & 7 & 3 & 3 & 8 & 8 & & \\
\hline & & 8 & 3 & 4 & 7 & 8 & & \\
\hline & & 9 & 4 & 3 & 7 & 8 & & \\
\hline & & 10 & 3 & 4 & 7 & 8 & & \\
\hline & Jumlah & & 33 & 35 & 68 & 80 & & \\
\hline
\end{tabular}

Berdasarkan tabel 1. Dapat diketahui bahwa media pembelajaran TTS IPA Terpadu sangat valid dari segi bahasa, materi, penyajian dan kegrafikan. Dari segi bahasa media pembelajaran TTS IPA Terpadu memperoleh nilai 92,5\% dengan kategori sangat valid. Hal ini menunjukkan bahwa penulisan isi dari media pembelajaran TTS IPA Terpadu sudah sesuai dengan kaidah penulisan bahasa Indonesia yang baik dan benar. Dari segi materi media pembelajaran TTS IPA Terpadu memperoleh nilai $85,4 \%$ dengan kategori sangat valid. Berdasarkan data ini dapat diketahui bahwa media pembelajaran TTS IPA Terpadu sesuai dengan kurikulum 2013 baik dari segi indikator maupun tujuan yang ingin dicapai. Media pembelajaran TTS yang dikembangkan juga sesuai dengan kebenaran illmu. Hal ini karena, selain menggunakan literatur dari depdiknas penulis juga melakukan konsultasi dengan ahlli materi. Dari segi penyajian, media pembelajaran TTS IPA Terpadu juga menarik dan menyenangkan jika digunakan dalam pembelajaran. Kelengkapan penyajian juga Dari segi penyajian dan kegrafikan media sudah valid dari segi ukuran huruf, bentuk huruf dan paduan warna. Kelengkapan media pembelajaran TTS IPA Terpadu juga sudah valid. Selain itu gambar-gambar yang disajikan di dalam media juga menarik dan memiliki sumber gambar. 
Tahap selanjutnya adalah Uji praktikalitas. Praktikalitas adalah uji tingkat keterpakaian produk. Tahap ini dilakukan dengan memberikan angket praktikalitas kepada siswa kelas VII SMPN 56 Merangin. Hasil angket praktikaits dapat diihat pada tabel 2.

Tabel 2. Hasil praktikalitas media TTS IPA Terpadu

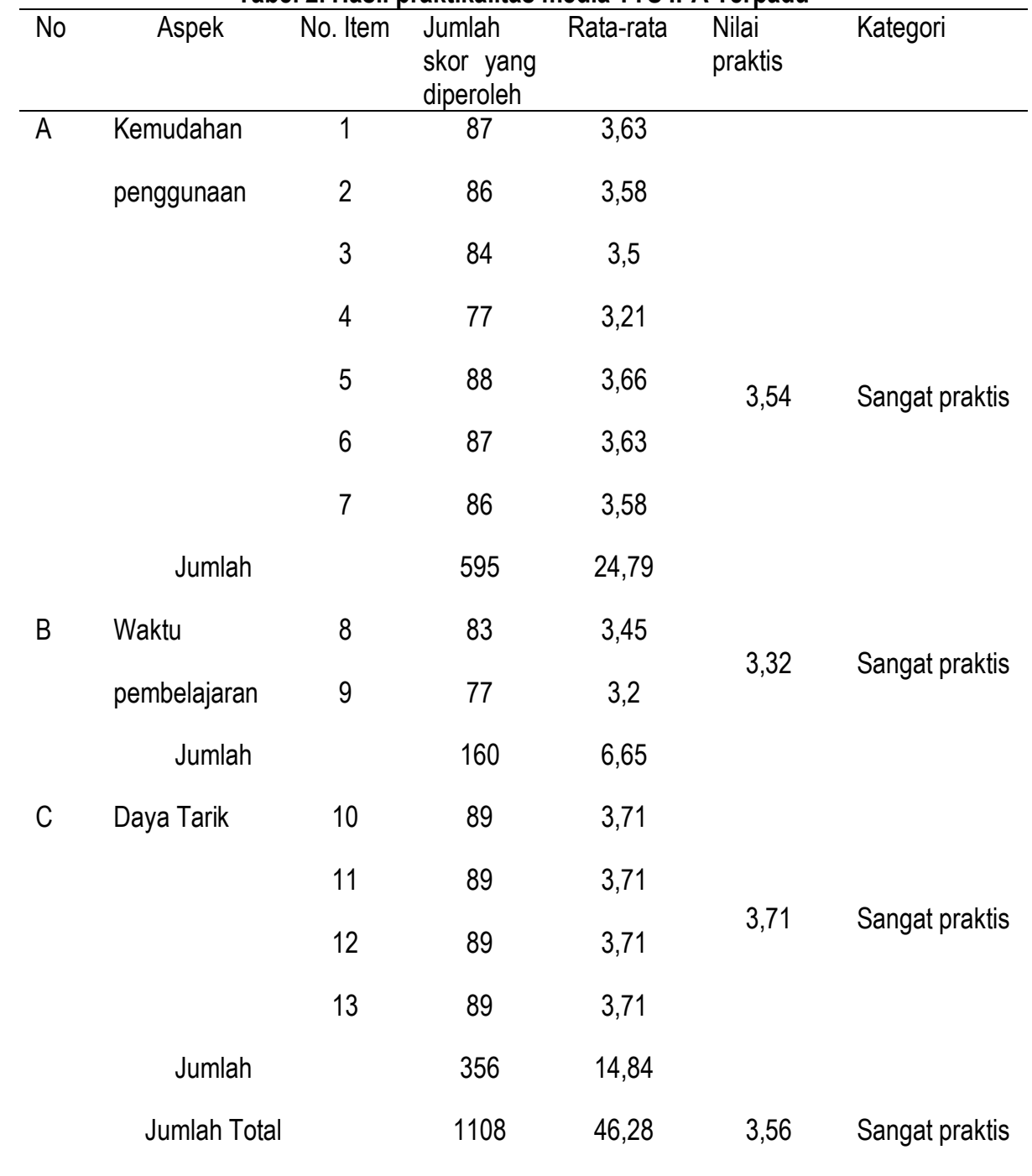

Berdasarkan tabel 2. Diketahui bahwa media TTS IPA Terpadu sangat praktis baik dari segi kemudahan penggunaan, waktu pembelajaran dan daya tarik. Tabel 2. Menunjukkan bahwa media pembelajaran TTS IPA Terpadu dapat digunakan. Dari segi kemudahan penggunaan media mendapat nilai praktis 3,54 dengan kategori sangat praktis. Hal ini dapat diartikan materi dan pertanyaan dalam media muda dipahami oleh siswa. Dari bentuk dan ukuran media ini mudah di bawa dan isi di dalam media ini dapat membantu memudahkan siswa mengingat dan menambah kosakata materi kasifikasi makhluk hidup dan klasifikasi materi dan perubahannya. Dari segi waktu pembelalajaran media ini medapat nilai praktis 3,32 dengan kategori sangat praktis. Data ini menunjukkan bahwa media dapat digunakan sesuai alokasi waktu pembelajaran di sekolah dan membuat waku pembelajaran menjadi efisien. Dari segi daya tarik media ini mendapat nilai praktis 3,71 dengan kriteria sangat praktis. Hal ini menunjukkan bahwa penyajian gambar, tulisan, materi dan pertanyaan sanagt menarik dan tidak membosankan. Selain itu media ini dapat memotivasi siswa untuk belajar.

Setelah media ini dinyatakan praktis, selanjutnya dilakukan uji efektifias dengan memberikan soal test kepada siswa untuk memperoleh data hasil belajar. Dalam hal ini, penelitian ini sama dngan penelitian (Wasgito, 2014) yang melakukan penelitian pengembangan sampsi tahap efektifitas media dengan meliha hasil belajar siswa. Mohamad Andi wasgito juga mengembangkan produk media TTS 
untuk siswa SMP akan tetapi pada mata pelajaran seni budaya sedangkan pada penelitian ini pada mata pelajaran IPA Terpadu. Hasil belajar siswa dapat dilihat pada Tabel 3.

Tabel 3. Hasil belajar menggunakan media TTS IPA Terpadu

\begin{tabular}{|c|c|c|c|c|}
\hline No & Nama & Nilai & KKM & Kategori \\
\hline 1 & $A P$ & 80 & 75 & Tuntas \\
\hline 2 & AA & 76 & 75 & Tuntas \\
\hline 3 & AS & 80 & 75 & Tuntas \\
\hline 4 & $A D$ & 60 & 75 & Tidak Tuntas \\
\hline 5 & AN & 86 & 75 & Tuntas \\
\hline 6 & $\mathrm{CR}$ & 98 & 75 & Tuntas \\
\hline 7 & DT & 76 & 75 & Tuntas \\
\hline 8 & DJ & 82 & 75 & Tuntas \\
\hline 9 & FA & 34 & 75 & Tidak Tuntas \\
\hline 10 & KA & 84 & 75 & Tuntas \\
\hline 11 & LG & 76 & 75 & Tuntas \\
\hline 12 & $\mathrm{MN}$ & 76 & 75 & Tuntas \\
\hline 13 & MR & 44 & 75 & Tidak Tuntas \\
\hline 14 & MY & 86 & 75 & Tuntas \\
\hline 15 & MU & 56 & $75 \mathrm{~T}$ & Tidak Tuntas \\
\hline 16 & $\mathrm{MB}$ & 82 & 75 & Tuntas \\
\hline 17 & NB & 54 & 75 & Tidak Tuntas \\
\hline 18 & RA & 82 & 75 & Tuntas \\
\hline 19 & SP & 76 & 75 & Tuntas \\
\hline 20 & SA & 88 & 75 & Tuntas \\
\hline 21 & SN & 96 & 75 & Tuntas \\
\hline 22 & WA & 78 & 75 & Tuntas \\
\hline 23 & WP & 56 & 75 & Tidak Tuntas \\
\hline 24 & $\mathrm{ZA}$ & 76 & 75 & Tuntas \\
\hline
\end{tabular}

Berdasarkan tabel 3. Diketahui bahwa KKM di sekolah adalah 75. Jumlah siswa yang tuntas adalah 18 orang dan yang tidak tuntas 6 orang. Sehingga persentase siswa yang tuntas adalah $75 \%$ dan siswa yang tidak tuntas $25 \%$. Peneliti terdahulu juga telah banyak menggunakan media TTS dalam proses pembelajaran. Salah satu contohnya adalah penelitian (Akbar \& Arbi, 2018). Pada penelitiannya hasil belajar meningkat dari kriteria kurang baik menjadi baik. Kelebihan penelitian ini adalah produk dikembangkan terlebih dahullu sehingga teruji kevalidannya. Sedangkan kelemahannya adalah proses pengembangan yang memerlukan waktu yang lama. Selain itu, penelitian ini tidak mengamati aktifitas siwa sebagai salah satu komponen penilaian siswa.

Setelah produk yang dikembangkan valid dan efektif maka selanjutnya produk disebarkan. Tahap penyebaran ini dilakukan di SMPN 56 Merangin dan SMP 6 Merangin. Jumlah poduk yang disebarkan adalah 50 produk TTS IPA Terpadu. Penyebaran dilakukan pada bulan oktober 2020. Kepala sekolah dan guru bidang studi sangat menyambut baik dan berharap ada pengembangan media-media pembelajaran terus dilakukan.

\section{SIMPULAN}

Kesimpulan dari penelitia ini adalah media pembelajaran TTS IPA Terpadu yang dihasilkan sangat valid baik dari aspek bahasa, materi, penyajian dan kegrafikan. Dari aspek bahasa media ,mendapat nilai validitas 92,5 aspek materi $85,4 \%$,aspek penyajian dan kegrafikan $85 \%$. Media ini juga dapat digunakan dalam proses pembelajaran dengan kriteria sangat praktis. Nilai prakikalitas yang 
diperoleh adalah 3,54 dari aspek kemudahan penggunaan, 3,32 dari aspek waktu pembelajaran, dan 3,71 dari aspek daa tarik. Ketuntasan hasil belajar menggunakan media TTS IPA Terpadu adalah $75 \%$. Penyebaran produk dilakukan di SMP 56 Merangin dan SMP 6 Merangin.

\section{UCAPAN TERIMA KASIH}

Ucapan terimakasih penulis sampaikan kepada seluruh pihak yang mendukung penelitian ini. Kepada Kepala Sekolah SMPN 56 Merangin bapak Iman sukiman nababinhaq S.Pd dan kepada guru bidang studi IPA Terpadu ibu Nurlela S.Pd yang telah mengizinkan penulis melakasanakan peneitian. Terimakasih kepada seluruh civitas akademik STKIP YPM Bangko yang telah memberikan dukungan sehingga penelitian ini dapat dilaksanakan

\section{RUJUKAN}

Akbar, M. N., \& Arbi, N. A. (2018). Application of crossword puzzles multimedia to increase student 's learning outcome on motion system material of biology. 178-183.

Lestari, Y., \& Sb, N. S. (2017). Development of Crossword Puzzles as Teaching Tools in Explanatory Texts Learning. 75-82.

M.Pd, S. M., \& Kurniawan, D. T. (2017). Implementsi Pemanfaatan Media Teka Teki Silang (TTS) Online Dalam Matakuliah Neurosains Untuk Mahasiswa Calon Guru Raudhatul Athfal (RA). AWLADY : Jurnal Pendidikan Anak, 3(2), 124. https://doi.org/10.24235/awlady.v3i2.1487

Nazeer, M., Sultana, R., Ahmed, M. M., Asad, M. R., Sami, W., Hattiwale, H. R., \& Sreekanth, T. (2018). Crossword Puzzles as an Active Learning Mode for Student Directed Learning in Anatomy Teaching: Medical Undergraduate Perceptions. International Journal of Medical Research \& Health Sciences, 7(10), 12-19.

Riduwan. (2006). Belajar mudah penelitian untuk guru - karyawan dan peneliti pemula / Riduwan. 241244.

Sadikin, A., Johari, A., \& Suryani, L. (2020). Pengembangan multimedia interaktif biologi berbasis website dalam menghadapi revolusi industri 4.0. Edubiotik: Jurnal Pendidikan, Biologi Dan Terapan, 5(01), 18-28.

Slameto. (2016). Belajar dan faktor-faktor yang mempengaruhi / Slameto. Belajar Dan Faktor-Faktor Yang Mempengaruhi / Slameto, 2003(2003), 1-99.

Sugiono. (2011). metode penelitian pendidikan (pendekatan kuwantitatif,kuwalitatif,R\&D). Alfabbeta Pres, 77-97.

Wasgito, M. A. (2014). Pengembangan Media Permainan Edukatif Teka-Teki Silang ( Tts ) Dalam Proses Pembelajaran Siswa Kelas Vii Smp Negeri 2 Kalianget. Jurnal Pendidikan Seni Rupa, 2(3), 36-43. 